\title{
Dry summers over northeastern South Africa and associated circulation anomalies
}

\author{
H. M. Mulenga*, M. Rouault, C. J. C. Reason \\ Oceanography Department, University of Cape Town, Private Bag, Rondebosch 7701, South Africa
}

\begin{abstract}
Circulation anomalies associated with dry summers over northeastern South Africa are considered. Dry summers occurring during El Niño/Southern Oscillation (ENSO) episodes are examined separately from those during non-ENSO years, for which a greater mid-latitude influence on South African summer rainfall is evident. During the ENSO dry summers, anomalous upper tropospheric westerlies are dominant over most parts of the subcontinent and make the upper flow unfavourable for rain-bearing disturbances over northeastern South Africa. The barotropic instability criterion is not satisfied over most of tropical southern Africa and the maximum baroclinic shear south of Africa tends to be shifted west into the Southeast Atlantic; thus, conditions are unfavourable for tropical-extratropical cloud-band development and South African rainfall. High-pressure anomalies exist over southern Africa, suppressing convection, while the ascending branch of the Walker Circulation shifts offshore into the western Indian Ocean to lie over anomalously warm sea-surface temperatures (SSTs) there. During the non-ENSO dry summers, there is a less obvious indication of significant warming of SST over the southwest Indian Ocean or coherent offshore shift in the Walker Circulation. Instead, mid-latitude circulation anomalies tend to play a larger role such that increased advection of cool, dry South Atlantic air occurs over South Africa with an increased mid-latitude westerly influence. The location of maximum westerly shear is shifted westwards, and conditions are generally unfavourable for cloud-band occurrence across South Africa; hence, rainfall is reduced.
\end{abstract}

KEY WORDS: Northeastern South African rainfall $\cdot$ Circulation anomalies $\cdot$ ENSO and non-ENSO droughts $\cdot$ Composite analysis

\section{INTRODUCTION}

The region of interest in this study, northeastern South Africa, is prone to significant drought and flood events; together with neighbouring southern Mozambique, it experienced devastating floods in February 2000. It is an important agricultural region with a relatively large rural subsistence population and also contains the Kruger National Park. Significant drought and flood events in this region can therefore impact severely at both local and national levels. A better understanding of the mechanisms associated with these events is of great importance in improving seasonal forecasts and the mitigation of adverse impacts.
The global and regional precipitation and circulation patterns during extreme El Niño/Southern Oscillation (ENSO) events have been studied previously (Ropelewski \& Halpert 1987, 1989, 1996, Kiladis \& Diaz 1989, Reason et al. 2000, Richard et al. 2000, Cook 2001). El Niño events tend to be associated with dry conditions over much of southeastern Africa (Ropelewski \& Halpert 1987, Janowiak 1988, Nicholson \& Kim 1997). ENSOrelated sea-surface temperature (SST) anomalies may affect rainfall over southeastern Africa through modification of the Walker and Hadley circulations and midlatitude storm tracks (e.g. Lindesay 1988).

In southern Africa, the occurrence of extreme summer rainfall anomalies (droughts and floods) has been linked to tropospheric circulation changes (Tyson 


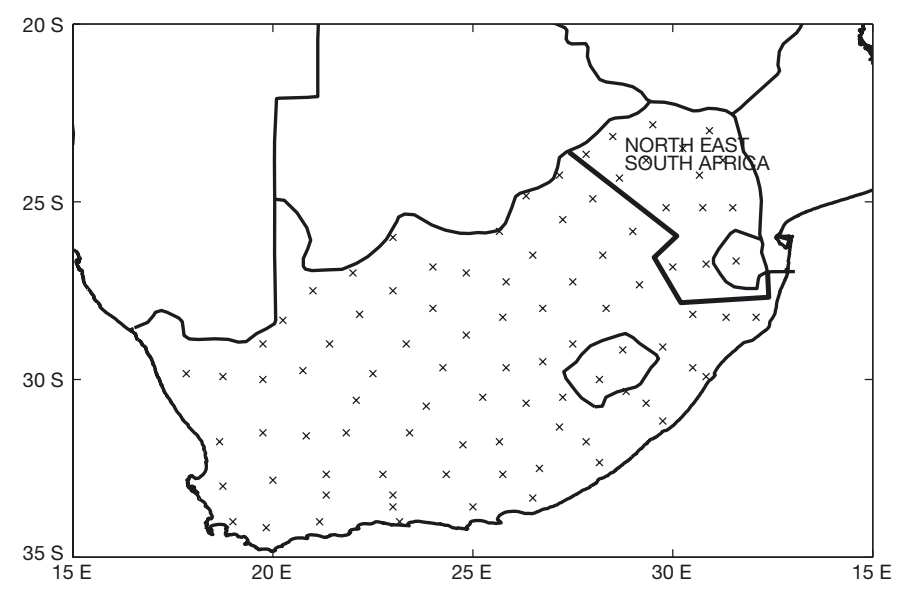

Fig. 1. Study region of northeastern South Africa and Swaziland (Area 8). $\times$ : rainfall district

1981, 1984, Miron \& Tyson 1984, van Heerden et al. 1988, Barclay et al. 1993, D'Abreton et al. 1993), quasibiennial oscillations (Mason \& Lindesay 1993, Jury et al. 1994), regional SST anomalies (Walker 1990, Goddard \& Graham 1999, Landman \& Mason 1999, Reason 1999, 2001, Reason \& Mulenga 1999, Jury et al. 2000) and ENSO (van Heerden et al. 1988, Jury et al. 1994, Rocha \& Simmonds 1997, Reason et al. 2000, Richard et al. 2000).

In this paper, the circulation changes associated with strong ENSO-related droughts in northeastern South Africa as well as those significant droughts in this region that do not occur during ENSO events are investigated using NCEP/NCAR Reanalysis data (Kalnay et al. 1996). The purpose of the study is to use these data to investigate, in greater detail than previously, the circulation patterns associated with droughts during ENSO events and also to see how such patterns may differ from those found during droughts that occur in other years (non-ENSO droughts). Since ENSO is primarily a tropical Indo-Pacific phenomenon, it is natural to consider whether ENSO droughts over southeastern Africa essentially arise from modulations to the local Walker Circulation and SST in the neighbouring tropical Indian and Atlantic oceans, while non-ENSO droughts might involve greater influences from the mid-latitudes. Much of southeastern Africa's summer rainfall arises from tropical-extratropical cloud-bands and associated disturbances; hence, both tropical and mid-latitude influences on regional rainfall may be considered. Widespread rain typically occurs over South Africa when the cloud-band stretches northwest-southeast from its tropical source (heat low over southern Angola-northern Namibia) to a mid-latitude disturbance southeast of South Africa (Harrison 1984). Thus, factors that change the location and intensity of the tropical and mid-latitude systems are therefore likely to influence cloud-band occurrence and hence rainfall. Regional drought may therefore arise from either local or remote forcing (or a combination) that acts to shift preferential areas of tropical and midlatitude weather, suppresses convection or otherwise makes conditions less favourable for cloud-band occurrence across South Africa.

Section 2 discusses the data and methodology followed in this study. The circulation changes associated with ENSO droughts are given in Section 3, while Section 4 deals with those associated with non-ENSO droughts. A synthesis of the results and conclusion are provided in the final section.

\section{DATA AND METHODS}

Summer (DJF) rainfall data for northeastern South Africa (Fig. 1) was obtained from the South African Weather Service for the 1921-2000 period. The region considered is known as homogeneous rainfall Area 8, based on a cluster analysis of South African rainfall (South African Weather Bureau 1972). These data were then area-averaged to form a northeast rainfall index for each austral summer, and standardized anomalies are plotted in Fig. 2. The National Center for Environmental Prediction (NCEP) Reanalysis data (Kalnay et al. 1996) are used to assess circulation changes associated with ENSO and non-ENSO droughts. This study utilises the NCEP data with a monthly time resolution and a spatial resolution of $2.5^{\circ}$ latitude $\times 2.5^{\circ}$ longitude. It should be noted that the spatial resolution of these reanalysis data does not resolve the topographic details of northeastern South Africa well, and therefore we have used station rainfall data to determine the dry summers. However, for the purpose of analysing the large-scale circulation anomalies over the South Atlantic-Africa-south Indian Ocean region that may be associated with rainfall variability, the NCEP resolution is adequate. Indeed, a number of climate variability studies for Australia and elsewhere in the Southern Hemisphere have used NCEP Reanalysis data in a similar way (e.g. Kiladis \& Mo 1988, Mo 2000, Godfred-Spenning \& Reason 2002). It is noted that some problems have been identified in the reliability of NCEP Reanalysis data for the 1950 and 1960s, prior to the availability of satellite data; thus, the data during this period should be treated with caution. The quality and validity of the NCEP Reanalysis data have been discussed in a recent monograph on Southern Hemisphere meteorology (Karoly \& Vincent 1998). Over Africa, regional advantages and disadvantages of the data have been documented (Trenberth \& Guillemont 1998, Camberlin et al. 2001, Grist \& Nicholson 2001). 
The severe ENSO and non-ENSO droughts are then defined as those for which the summer rainfall is equal to or falls below 1 standard deviation from the mean. Circulation changes during those droughts in the 1949-2000 period for which NCEP Reanalysis data are available are investigated. It is important to note that there were significant dry summers in various years prior to 1949 (e.g. early 1940s, late 1920s); however, these cases are not considered herein. It is also noteworthy that the region has experienced some significant wet years, most notably in the 1970s and in 1995/6 and 1999/00. The nature of these wet years, possible ENSO relationships, and associated circulation patterns will be investigated in a subsequent paper.

For the post-1949 period, Fig. 2 indicates that the region experienced severe drought as defined above during the following strong ENSO summers: 1972/73, 1982/83, 1991/92 and 1997/98. Strong ENSO years are as defined in Allan et al. (1996) and Reason et al. (2000) on the basis of departures in SOI (Southern Oscillation Index) and SSTA (Sea Surface Temperature Anomalies) in the Niño 3 and Niño 4 regions. There are also significant dry summers during non-ENSO summers; namely, in 1950/51, 1951/52, 1962/63, 1967/68 and $1981 / 82$. Investigation of the circulation and SST fields during these years indicated that a composite approach to the analysis of the ENSO droughts was warranted, consistent with previous ENSO studies (e.g. Rasmusson \& Carpenter 1982, Ropelewski \& Halpert 1989, Allan et al. 1996, Reason et al. 2000). To

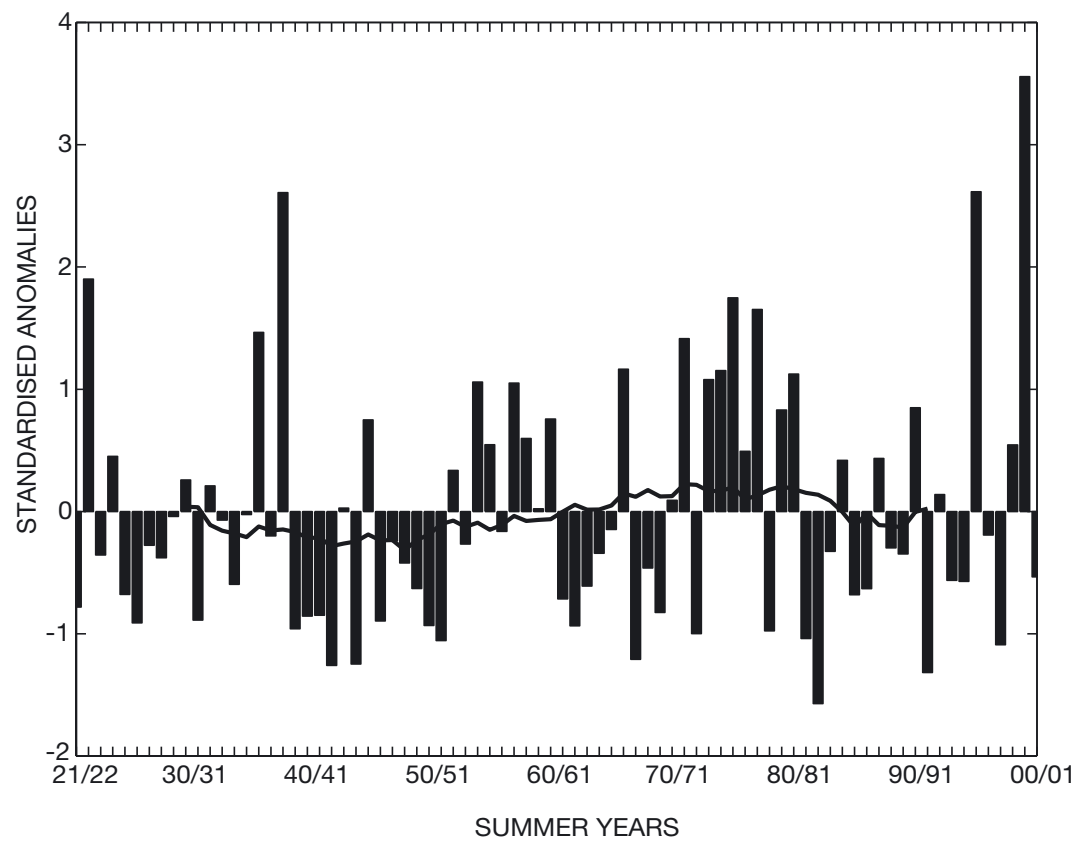

Fig. 2. Time series of standardised summer (December-February, DJF) rainfall index values (bars) over northeastern South Africa (Area 8) and the $20 \mathrm{yr}$ running mean (line) assess the sensitivity of this analysis, composites were also formed with the strong ENSO of 1986/87 included and little difference was found. Note that the summer of 1986/87 was the next driest strong ENSO case (about $0.75 \sigma ; \sigma$ is the $\mathrm{SD}$ of the summer index) for northeastern South Africa during the 1949-2000 period.

Although the ENSO summers already mentioned appeared to have sufficient commonality in the circulation and SST fields for a compositing approach to be a useful way of focusing on the salient features, this was not the case for the various non-ENSO drought years. These years tended to show strong mid-latitude influences on the rainfall, particularly via shifts in the ridges and troughs of wavenumber 3 (Tyson 1986, Karoly \& Vincent 1998). Compositing tended to smear out these shifts, and it is preferable to consider the cases individually so as to demonstrate how these midlatitude differences can also significantly impact on rainfall over northeastern South Africa. Focus is placed on the 3 most severe post-1949 non-ENSO droughts, namely 1951/52, 1967/68 and 1981/82.

\section{CIRCULATION CHANGES ASSOCIATED WITH ENSO DROUGHTS}

In this section, the circulation changes associated with the ENSO drought years are considered. Previous work (e.g. Lindesay 1988, Jury 1992, Cook 2000, Reason et al. 2000) has found evidence for an offshore shift of the ascending branch of the local Walker Circulation so that it lies over the western Indian Ocean rather than over southern Africa during ENSO. Such a shift tends to result in dry conditions, since it is favourable for the offshore shift of tropicalextratropical cloud-bands that are important for summer rainfall over South Africa (Harrison 1984, PrestonWhyte \& Tyson 1988). Thus, when the local Walker Circulation ascends over tropical southern Africa, the cloud-bands extend southeast from southern Angola and out over the southeast coast of South Africa, resulting in significant rain over northern and eastern South Africa.

Idealized modelling studies by Cook (2000) suggest that some droughts over southern Africa could possibly be linked to ENSO-driven warm SST over the Pacific Ocean through atmos- 


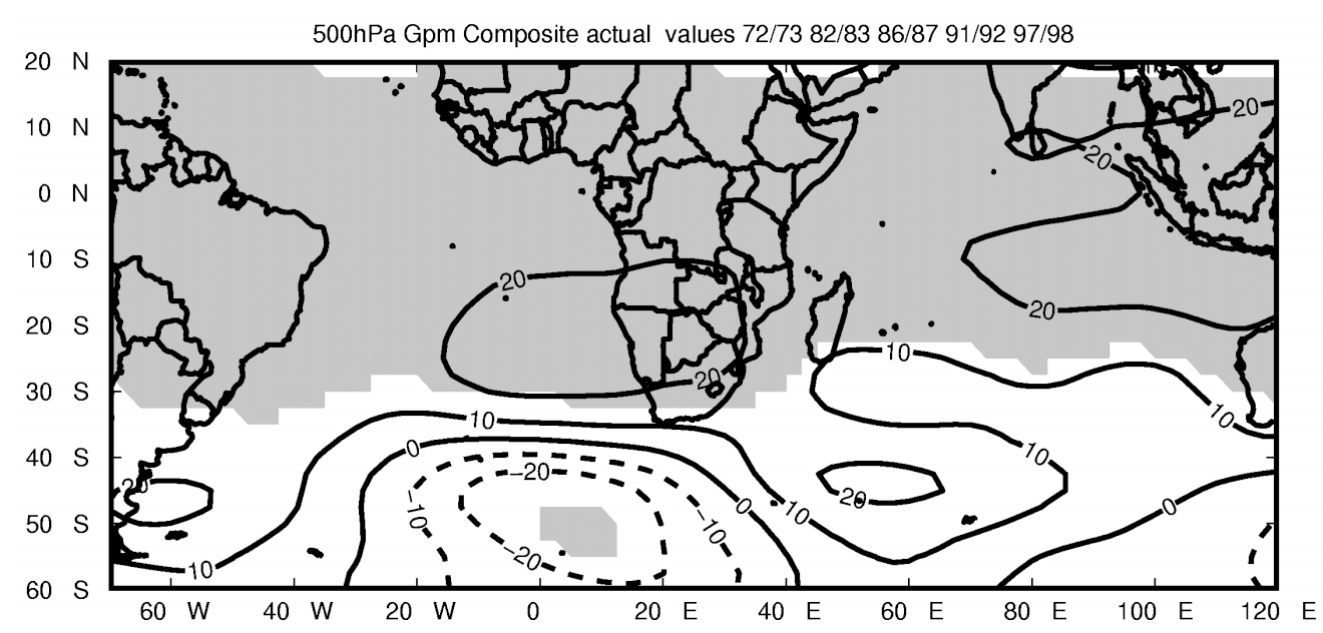

Fig. 3. Composite DJF geopotential height anomalies at $500 \mathrm{hPa}$ (interval = $10 \mathrm{gpm})$ based on ENSO droughts $(1972 / 73,1982 / 83$, 1986/87, 1991/92 and 1997/98). Shaded regions indicate where the anomalies are statistically significant at the $95 \%$ level. Negative values are indicated by dashed contours

pheric teleconnections via the propagation of Rossbywave-like features. Upper-level convergence over the tropical eastern Indian Ocean-Indonesia region acts as a source for these Rossby-wave-like features that propagate the signal southwestwards across the Indian Ocean to impact on southern Africa. By the ENSO mature phase (January-March season or austral summer following the first significant warming in the equatorial Pacific), large-scale positive pressure anomalies extend across the Indian Ocean-southern Africa region (e.g. ENSO composites of mean-sea-level pressure [MSLP] and $500 \mathrm{hPa}$ geopotential anomalies shown in Kiladis \& Mo [1998] and Reason et al. [2000]). Fig. 3, showing the $500 \mathrm{hPa}$ geopotential anomaly for

72/73 82/83 86/87/ 91/92 97/98 850hPa WIND COMPOSITE ANOMALIES (m/s)

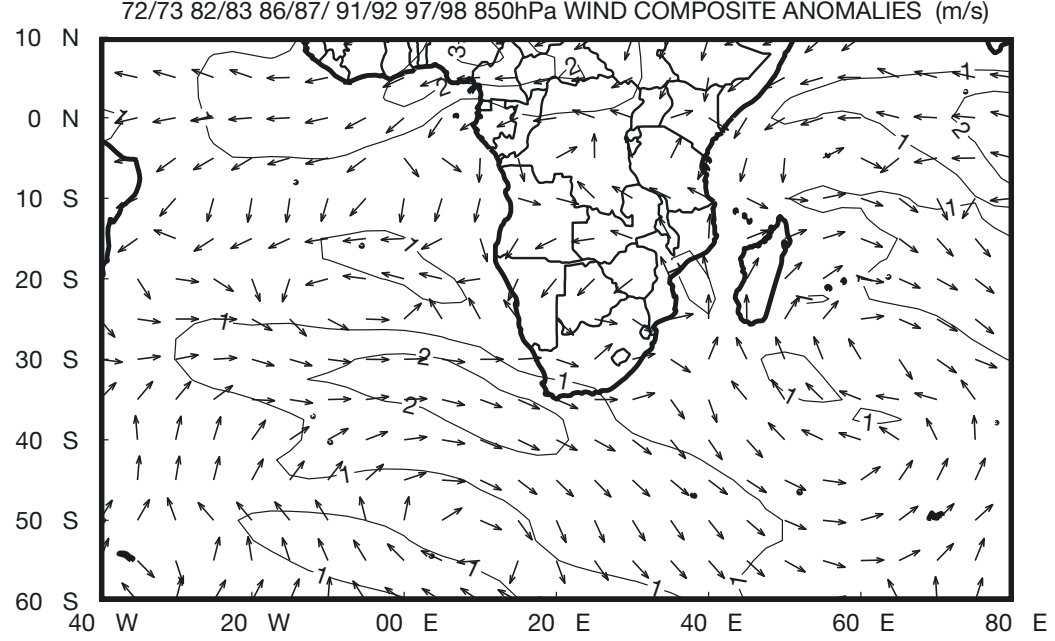

Fig. 4. Composite DJF wind anomalies at $850 \mathrm{hPa}\left(\right.$ interval $=1 \mathrm{~m} \mathrm{~s}^{-1}$ ) based on ENSO droughts the ENSO drought summers, is consistent with these results, and unfavourable conditions for tropical convection and cloud-band alignment over southern Africa are suggested. The positive height anomalies centred over Namibia and southern Angola act to weaken the continental Angola-Botswana low, thus reducing the development of easterly waves and the formation of cloud-bands.

In the southeast Atlantic Ocean region, Fig. 3 and the MSLP composite (not shown) suggest an equatorward expansion of the mid-latitude westerlies and an increased tendency for a drier South Atlantic air-mass to be advected over South Africa, consistent with the earlier conceptual model of Tyson (1986) that was derived from station data. While these circulation changes suggest an increased westerly influence over the southeast Atlantic region, the positive anomalies south and southeast of South Africa imply that the mid-latitude systems are more likely to be weaker and to track further offshore from the land-mass (i.e. poleward). As a result, the mid-latitude link and westerly trough development over this part of the southwest Indian Ocean that is needed for extensive cloud-band formation is far less likely to occur during these summers.

The South Atlantic inflow which feeds into the generally anticyclonic circulation over subtropical southern Africa is clearly evident at the $850 \mathrm{hPa}$ level (Fig. 4) or just above the height of the interior plateau. At $700 \mathrm{hPa}$, the anticyclonic anomaly (not shown) is 


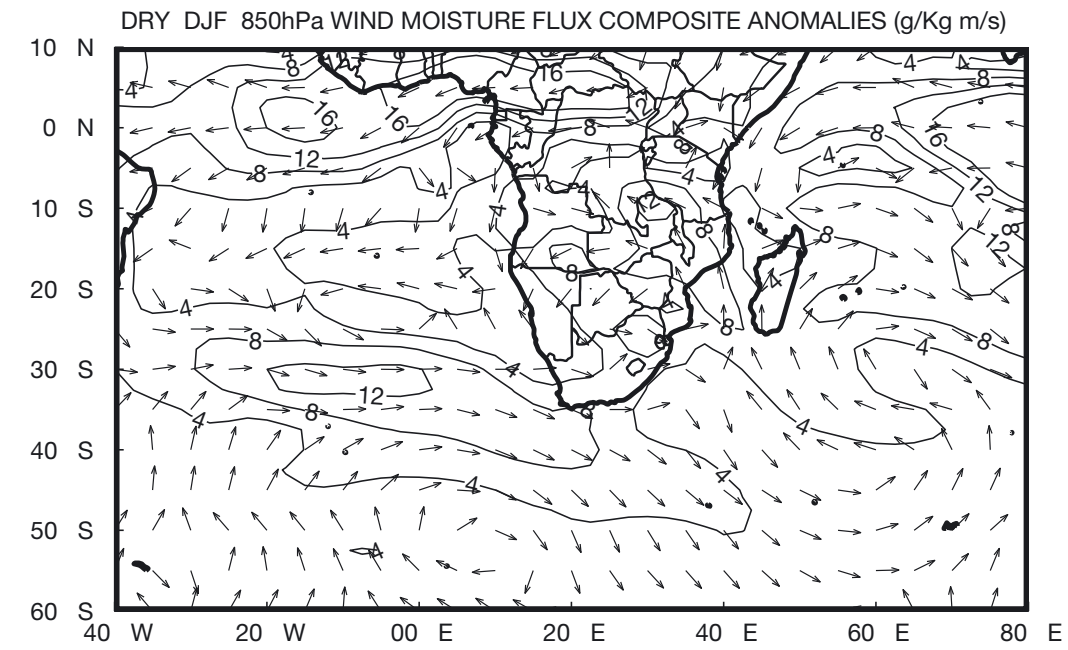

Fig. 5. Composite of the circulation moisture flux at $850 \mathrm{hPa}$ for ENSO droughts. Arrows show the direction of the vector fluxes and units are $\mathrm{g} \mathrm{kg}^{-1} \mathrm{~m} \mathrm{~s}^{-1}$ (divergence) (Fig. 7) across the northwest-southeast-oriented band from Angola across Botswana and Zimbabwe to eastern South Africa (in the tropical western Indian Ocean) is consistent with the anticyclonic circulation over the subcontinent, with reduced rainfall there, and with the offshore shift of the Walker Circulation and associated convection.

Further evidence of unfavourable conditions for cloud-band formation and rainfall is provided by the changes in vertical shear (baroclinic instability) and in the criterion for barotropic instability. It should be noted that these results should be viewed as indicative rather than conclusive, since the relatively coarse resolution of the NCEP Reanalysis data means that calculations of derived meteorological parameters found to be centred over Botswana, again discouraging tropical convection and cloud band formation. At $200 \mathrm{hPa}$ (not shown), the westerly anomalies over Angola and Zambia reflect a weakening of the mean flow associated with the location of the ITCZ here while the stronger westerlies southwest of South Africa and weaker to the southeast are consistent with the unfavourable shifts in mid-latitude storm tracks already mentioned.

The analyses presented so far essentially confirm the circulation anomalies occurring during ENSO events that were inferred by previous workers from the limited data sets available at the time (e.g. Harrison 1984, Lindesay 1988). To extend this further, we consider anomalies in moisture flux, convergence in this moisture over southern Africa and various instability criteria. The low- to mid-level anticyclonic circulation over subtropical southern Africa weakens the input of moisture from the relatively warm southwest Indian Ocean as confirmed by the $850 \mathrm{hPa}$ moisture flux anomalies (Fig. 5). Increased moisture flux is seen over the tropical western Indian Ocean consistent with the ascending branch of the local Walker Circulation being located there rather than over tropical southern Africa during ENSO and with high-pressure anomalies extending out over the Indian Ocean from Australasia. The enhanced divergence (convergence) at $700 \mathrm{hPa}$ (Fig. 6) and upper-level convergence such as wind shear and the barotropic instability criterion are appropriate only for large scales (on the order of $1000 \mathrm{~km}$ ). The barotropic instability criterion is given as $\beta-\mathrm{d}^{2} U / \mathrm{d} y^{2}=0$, where $\beta$ is the gradient of the Coriolis parameter and $\mathrm{d}^{2} U / \mathrm{d} y^{2}$ is the second partial derivative of the zonal wind. The distribution of vertical shear (the difference between 200 and $850 \mathrm{hPa}$ zonal wind) for the ENSO years shows easterly shear in the equatorial region and westerly shear in the subtropics (Fig. 8). During ENSO years, there is a westward shift in position $\left(20^{\circ} \mathrm{E}\right.$, $\left.40^{\circ} \mathrm{S}\right)$ of the maximum shear $\left(>25 \mathrm{~m} \mathrm{~s}^{-1}\right)$ compared with the long-term mean position $\left(30^{\circ} \mathrm{E}, 40^{\circ} \mathrm{S}\right)$. This shift suggests a tendency for the baroclinic waves and hence the

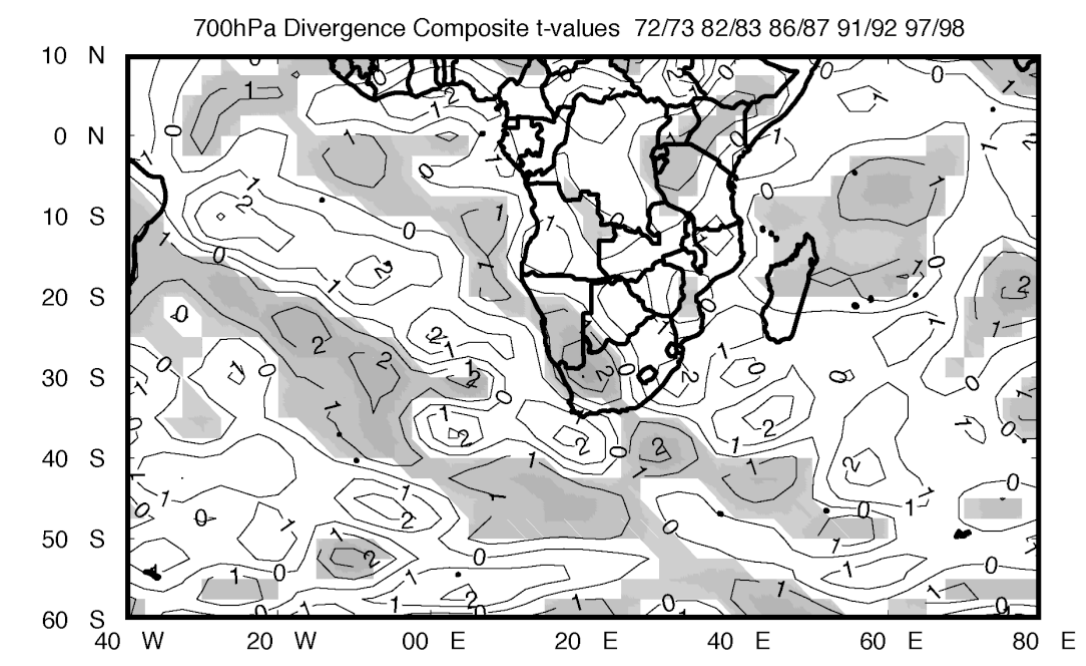

Fig. 6. Composite of DJF divergence anomalies at $700 \mathrm{hPa}$ (interval $=0.5 \times$ $1000 \mathrm{~s}^{-1}$ ) for the ENSO droughts. Shaded areas denote negative values. $t$-values greater than 2 are significant at the $95 \%$ level 


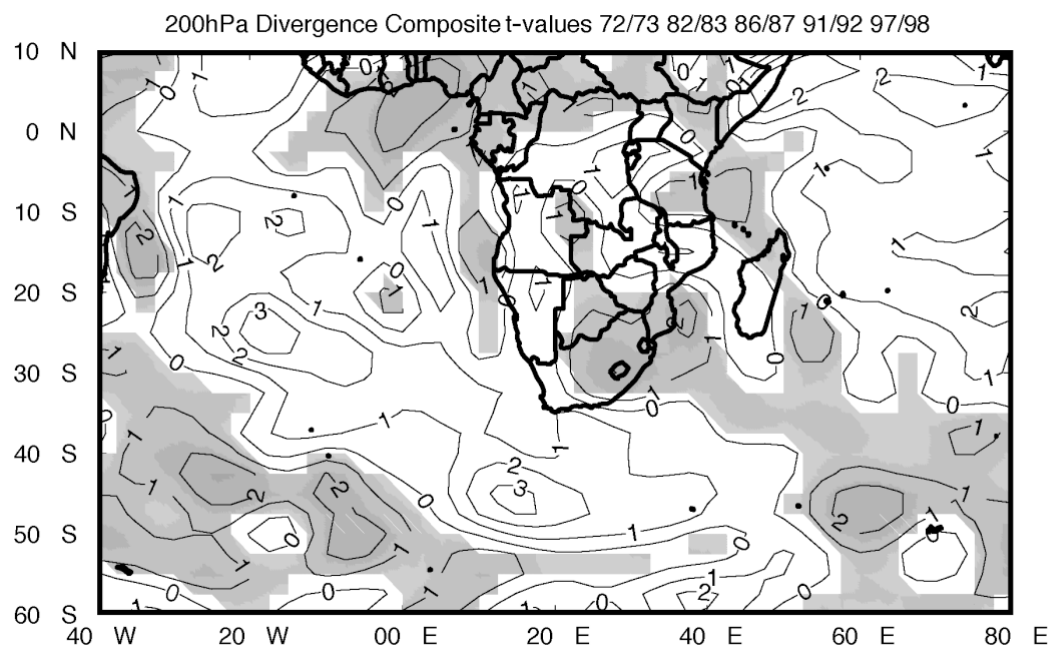

Fig. 7. Composite of DJF divergence anomalies at $200 \mathrm{hPa}$ for the ENSO droughts. For details see Fig. 6 mid-latitude part of the cloud-band (i.e. the frontal system) to be located further west, which is unfavourable for cloudband development across South Africa. The $200 \mathrm{hPa}$ barotropic instability criterion (Fig. 9) is met over the Congo Basin, Tanzania and Ethiopia, consistent with the tendency for above-average rainfall in those areas during ENSO. Over southern Africa, these increased westerlies means that the criterion is generally not met; thus, there are likely to be fewer barotropic disturbances and less chance of easterly waves/tropical depressions and cloudbands.

In summary, the anomalous circulation patterns during strong ENSO dry

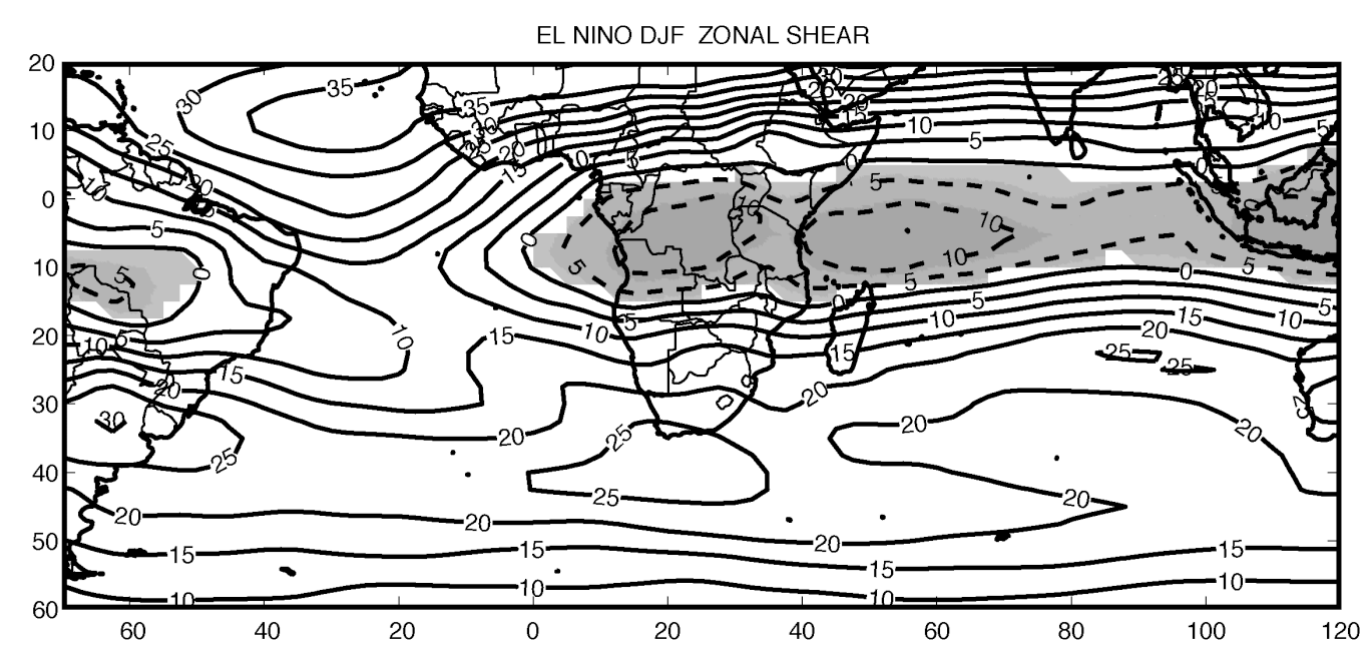

Fig. 8. Composite of the vertical shear of the zonal wind (interval $=5 \mathrm{~m} \mathrm{~s}^{-1}$ ) between 850 and $200 \mathrm{hPa}$ for the ENSO droughts. Shaded areas have negative values; dashed lines represent negative values

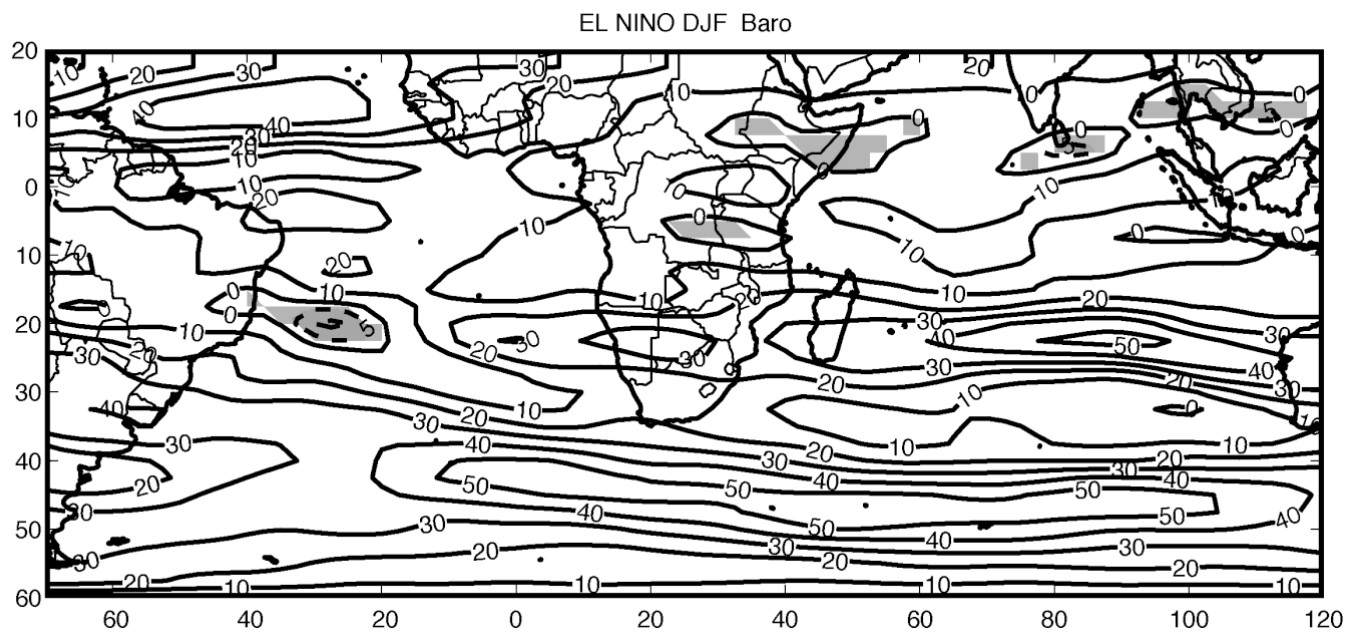

Fig. 9. Barotropic instability criterion evaluated at $200 \mathrm{hPa}$ for the ENSO droughts. Shaded areas have negative values; dashed lines represent negative values (interval $=5 \mathrm{~m}^{-1} \mathrm{~s}^{-1}$ ); continuous lines represent positive values (interval $=10 \mathrm{~m}^{-1} \mathrm{~s}^{-1}$ ) 
summers which discourage convection and cloudband formation across southern Africa are as follows:

- Anticyclonic conditions centred over Namibia and southern Angola with associated stable conditions and regional subsidence.

- Low-level divergence and upper-level convergence along a northwest-southeast-oriented band across southern Africa associated with an eastward shift of the ascending branch of the Walker Circulation and cloud-band occurrence over the Indian Ocean.

- Increased westerly flow in the mid-latitudes favouring more frontal systems over southwestern South Africa and advection of dry South Atlantic air over northern South Africa.

- Increased upper-level westerlies and the jet core positioned further westward.

- Reduced upper-level easterlies over low-latitude southern Africa which decreases the frequency and growth rate of tropical disturbances that are needed to promote the source of the cloud bands over this region.

While analysis of station data (e.g. in Tyson 1986, Lindesay 1988) has enabled some of the above points to be inferred previously, the NCEP Reanalysis discussed above confirms and extends these considerably. In particular, the assessment of the moisture flux, divergence, vertical wind shear and the barotropic instability criterion gives more confidence in the validity of these results.

\section{CIRCULATION ANOMALIES ASSOCIATED WITH NON-ENSO DROUGHTS}

The previous section discussed how the circulation anomalies that occur during northeast South African dry summers coinciding with strong ENSO events act to suppress convection and hence rainfall. These anomalies arise out of the re-organisation of the global tropical circulation that occurs during ENSO. As Fig. 2 has shown, there are several noticeably dry non-ENSO summers in northeastern South Africa, and the purpose of this section is to investigate their associated circulation patterns and mechanisms that may lead to reduced rains during these seasons. As a result of the greater mid-latitude influence that was found to occur for these droughts, it is preferable to look at specific cases individually rather than present composites which tend to smear out the extra-tropical features of influence. The 3 driest non-ENSO summers since 1949 - 1951/52, 1967/68 and 1981/82 - are considered below.

\subsection{Case 1: 1951/52}

Like the ENSO composite, the low- to mid-level circulation over southern Africa during the 1951/52 summer was also anticyclonic (Fig. 10); however, more pronounced negative anomalies are evident in the mid-latitudes and these extend into the tropical South Atlantic. The wind anomalies at $850 \mathrm{hPa}$ (not shown) suggest increased advection of dry South Atlantic air over much of South Africa, and there was little lowlevel inflow of moisture from the southwest Indian Ocean or Congo Basin (Fig. 11), consistent with what one would expect for a dry season. The moisture inflow from the western Indian Ocean over southern Africa occurred much further north during this season. Over southern Angola, moisture was transported off the continent rather than being imported from the tropical southeast Atlantic, as would have occurred if



Fig. 10. Geopotential height anomaly at $500 \mathrm{hPa}$ (interval = $10 \mathrm{gpm}$ ) for the DJF 1951/52 drought. Negative anomalies are shaded 


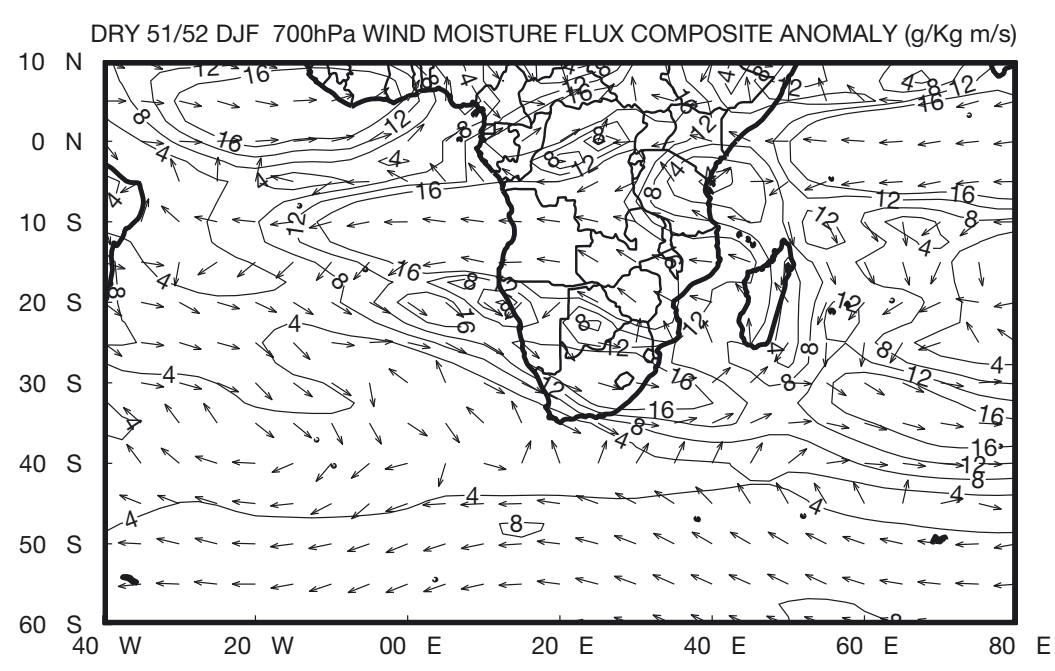

Fig. 11. Moisture flux anomaly at $700 \mathrm{hPa}$ (interval $=4 \mathrm{~g} \mathrm{~kg}^{-1} \mathrm{~m}^{-1} \mathrm{~s}^{-2}$ ) for the DJF 1951/52 dry summer. Arrows show the direction of the flux, and contours the magnitude

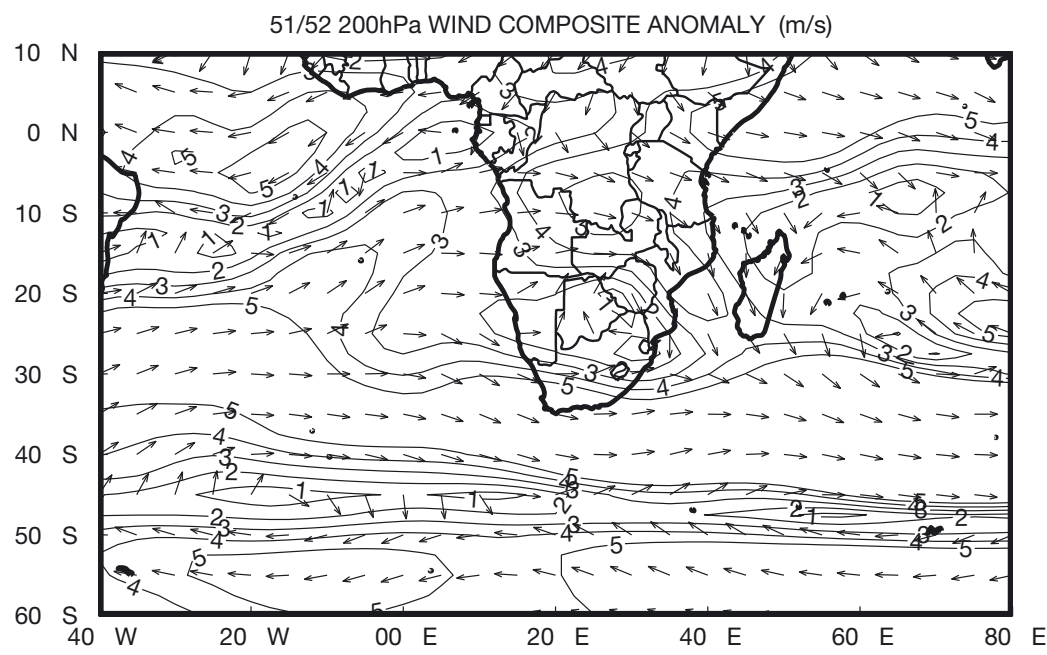

Fig. 12. Wind anomaly at $200 \mathrm{hPa}$ (interval $=4 \mathrm{~m} \mathrm{~s}^{-1}$ ) for the DJF 1951/52 dry summer the heat low was strong and cloudband generation was favoured.

Calculation of the barotropic instability criterion over the region indicated that this was only possibly satisfied over Madagascar and not on the mainland (not shown). The mid-latitude wind shear between 850 and $200 \mathrm{hPa}$ showed the maximum to be displaced westward to $22.5^{\circ} \mathrm{E}, 40^{\circ} \mathrm{S}$ (not shown), again unfavourable for cloud-bands across South Africa. The upper-level wind anomalies (Fig. 12) were westerly in both the tropics and mid-latitudes, suggesting a weakening of tropical convection over southern Africa and increased mid-latitude influence. The actual $200 \mathrm{hPa}$ flow itself is more reminiscent of a winter pattern, with maxima just east of South Africa. Relatively strong convergent anomalies were found (not shown) at $200 \mathrm{hPa}$ over the zone northwest-southeast from Angolan to South Africa implying reduced tropical convection and cloud-band occurrence.

\subsection{Case 2: 1967/8}

The 1967/68 summer is the driest non-ENSO season and is also drier than all the ENSO droughts identified in Fig. 2 except for 1982/83 and 1991/92. The circulation anomalies associated with the 1967/68 summer are also quite different from those shown for the ENSO composite or for the 1951/52 sea-

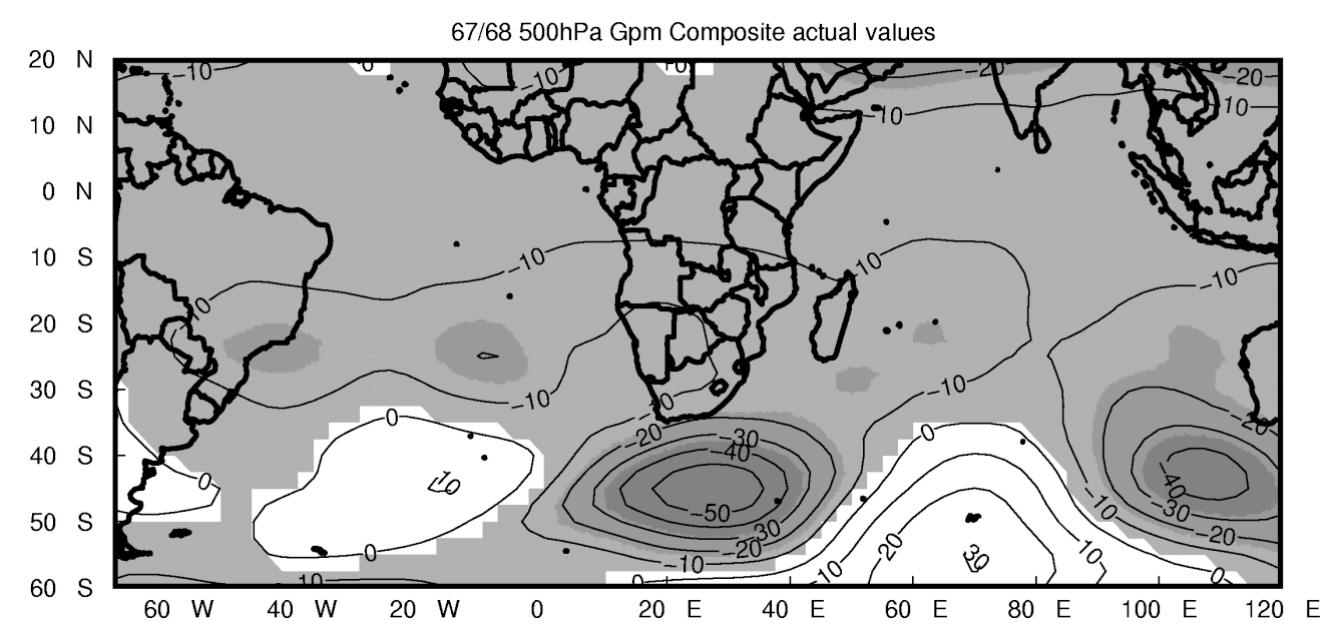

Fig. 13. Geopotential height anomaly at $500 \mathrm{hPa}$ (interval = $10 \mathrm{gpm}$ ) for the DJF 1967/68 dry summer 
son. The most prominent feature is a large cyclonic anomaly immediately south of South Africa with associated advection of cool, dry South Atlantic air over South Africa (Figs. 13 \& 14) and little inflow of moisture over northeastern South Africa from the Indian Ocean or the Congo Basin. Relative divergence was evident at the 850 $\mathrm{hPa}$ level over the zone northwest-southeast from Angola to eastern South Africa (not shown), discouraging tropical convection and cloud-band occurrence. The barotropic instability criterion was found to be unfavourable over southern Africa (not shown), and the vertical shear maximum occurred west $\left(20^{\circ} \mathrm{E}, 40^{\circ} \mathrm{S}\right)$ of its mean longitude (Fig. 15), discouraging cloud-bands over South Africa. The existence of a pronounced mid-latitude westerly influence over South Africa is also marked at the $200 \mathrm{hPa}$ level, where a strong westerly trough extends into low-latitude southern Africa (Fig. 16).

DRY 67/68 DJF 700hPa WIND MOISTURE FLUX COMPOSITE ANOMALY (g/Kg m/s)

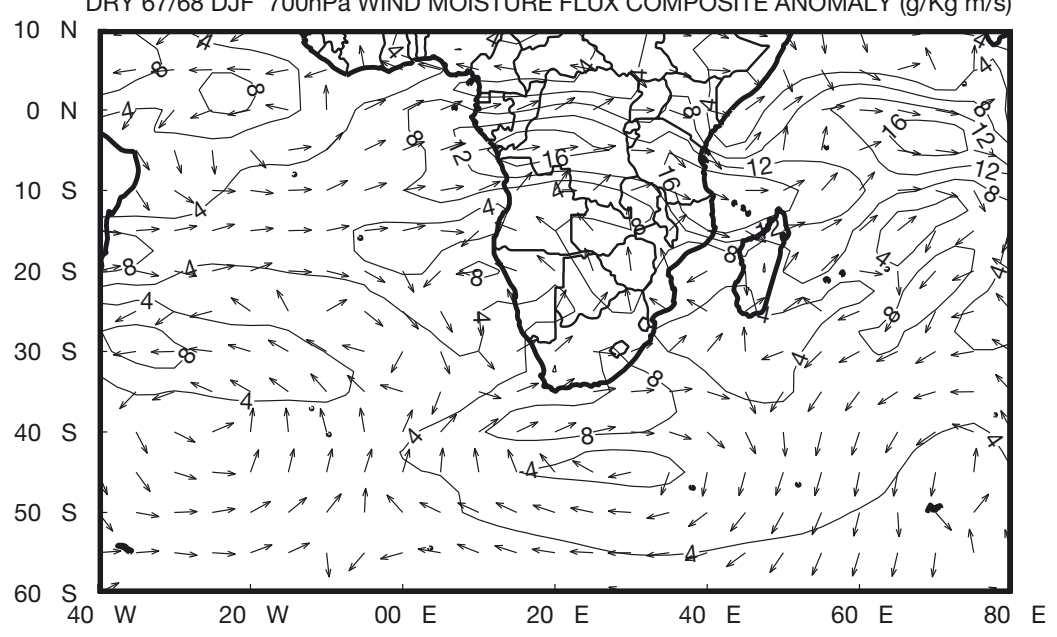

Fig. 14. Moisture flux anomaly at $700 \mathrm{hPa}$ (interval $=4 \mathrm{~g} \mathrm{~kg}^{-1} \mathrm{~m} \mathrm{~s}^{-1}$ ) for the DJF 1967/68 dry summer

\subsection{Case 3: 1981/82}

Like the ENSO composite, this season shows positive pressure anomalies over southern Africa (Fig. 17); however, there are also very strong anticyclonic anomalies over the neighbouring mid-latitude oceans which are still apparent at $200 \mathrm{hPa}$ (not shown). These midlatitude anticyclonic features are reflected in the moisture flux (Fig. 18) with relatively cool, dry South Atlantic air over western South Africa and a weakening of the onshore flow of moisture from the southwest Indian Ocean. Given the poleward shift of the south Indian Ocean anticyclone, the winds over the waters just east of South Africa become more northerly and less onshore, hence reducing the onshore advection of moisture. Furthermore, low-level divergent anomalies are again present over the zone northwest-southeast from Angola to eastern South Africa, and there are marked convergent anomalies at $200 \mathrm{hPa}$ (not shown) consistent with the dry conditions observed. The computed barotropic instability criterion at $200 \mathrm{hPa}$ (not shown) suggests reduced barotropic disturbances over southern Africa. The wind-shear maximum (>25 $\mathrm{m} \mathrm{s}^{-1}$ ) was again found to be west $\left(20^{\circ} \mathrm{E}, 40^{\circ} \mathrm{S}\right)$ of its mean position (Fig. 19) during this season, discouraging cloud-bands over South Africa.

\subsection{Summary}

A common feature of the non-ENSO droughts seems to be an increased mid-latitude influence on the circula-

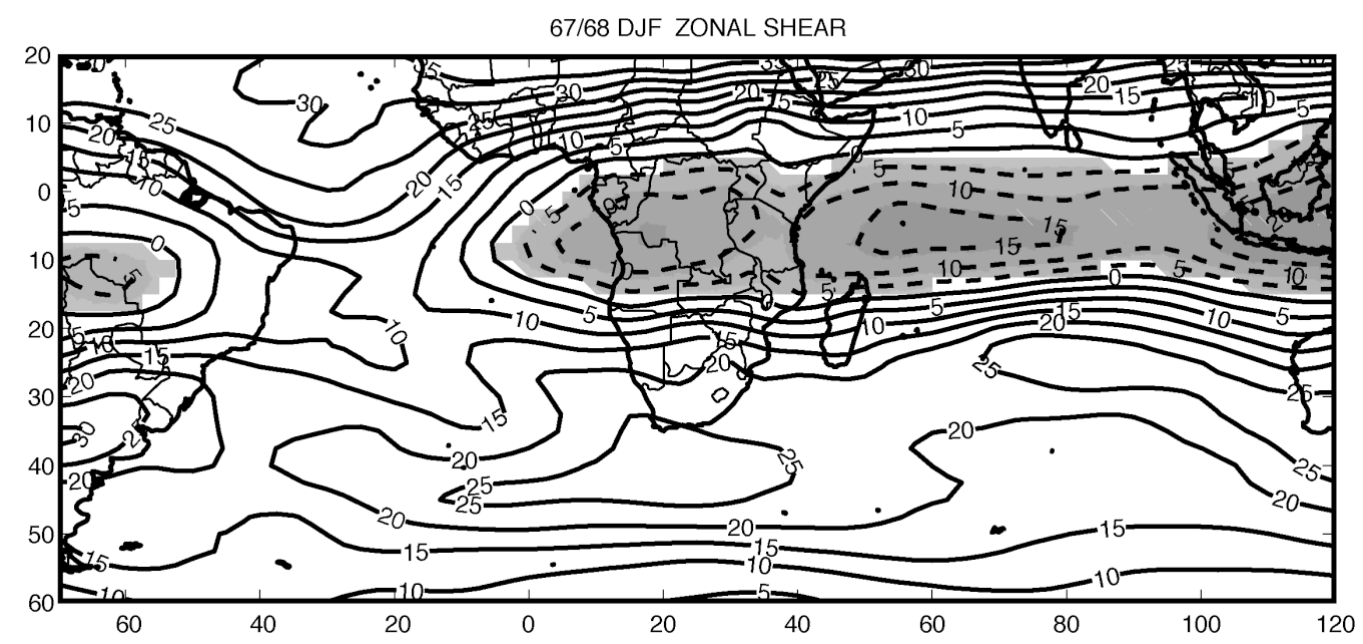

Fig. 15. Zonal wind shear between 850 and $200 \mathrm{hPa}$ (interval $=5 \mathrm{~m} \mathrm{~s}^{-1}$ ) for the DJF 1967/68 dry summer 
tion in the South African region and increased advection of cool, dry air from the south or southwest over the country. In the mid-latitudes, the maximum wind shear is shifted west from its average position, thereby discouraging the mid-latitude component of the cloud-bands from lying across South Africa. Relative divergence at the $850 \mathrm{hPa}$ level across a northwest-southeast band extending from Angola to eastern South Africa with a weakened or absent tropical low over Angola-northern Botswana is also noted. These common features are unfavourable for convection and cloud-band occurrence across northern South Africa leading to the dry conditions observed. It should be emphasized, however, that the significantly enhanced inflow of South Atlantic air and lowlevel divergence during these dry summers come about through different large-scale circulation patterns and hence do not stand out when composited together.

\section{DISCUSSION AND CONCLUDING REMARKS}

This study has considered the circulation anomalies and mechanisms potentially associated with extreme dry years in the summer rainfall region of northeastern South Africa. This region is important to southern Africa for agriculture, tourism and biodiversity and also contains a relatively large rural population. Severe drought (as defined by the seasonal rainfall being at least 1 standard deviation below the longterm mean) was found to occur during almost all strong ENSO events as well as during several non-ENSO years. Of the strong ENSO events that did not produce severe drought, 1986/87 was very dry (about $0.75 \sigma$ below the mean), 1965/66 relatively dry (about $0.2 \sigma$ ), 1963/64 very dry (about $0.75 \sigma), \quad 1941 / 42$ and 1940/41 very dry (about $0.8 \sigma$ each), and 1925/26 again very dry (about 0.75 $\sigma)$. In fact, the only strong ENSO event during the 1921-2001 period that did not appear to produce below-average rain over the region was 1957/58. Examination of NCEP Reanalysis data for this period suggest that this strong ENSO season was unusual in that high-pressure anomalies did not extend over southern Africa from the Indian Ocean-Australasia region as is more typical. Instead, there were

Fig. 16. Wind anomaly at $200 \mathrm{hPa}$ (interval $=1 \mathrm{~m} \mathrm{~s}^{-1}$ ) for the DJF 1967/68 dry summer

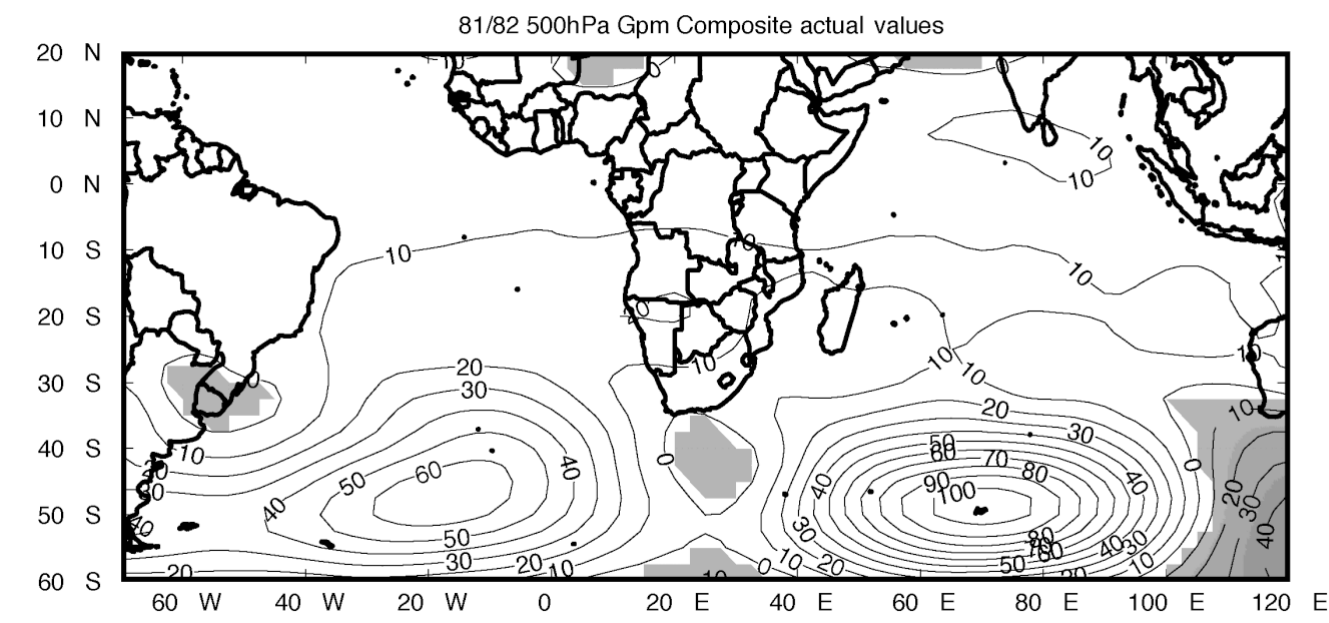

Fig. 17. Geopotential height anomaly at $500 \mathrm{hPa}$ (interval $10 \mathrm{gpm}$ ) for the DJF 1981/82 dry summer. Negative values are shaded 
DRY 81/82 DJF 700hPa WIND MOISTURE FLUX COMPOSITE ANOMALY (g/Kg m/s)

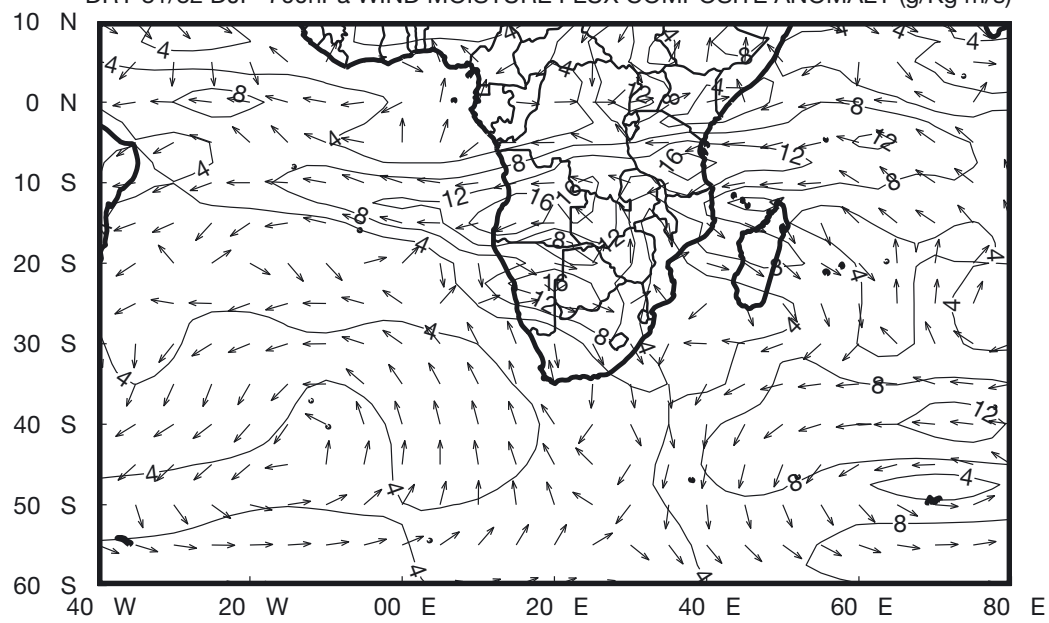

Fig. 18. Moisture flux anomaly at $700 \mathrm{hPa}$ (interval $4 \mathrm{~g} \mathrm{~kg}^{-1} \mathrm{~m} \mathrm{~s}^{-1}$ ) for the DJF 1981/82 dry summer

cyclonic anomalies over southern Africa favourable for above-average rainfall, as in fact occurred during this season.

Given that the mechanisms are different, it was decided to separately investigate strong ENSO dry summers from those that occurred during non-ENSO years. This investigation was restricted to the 1949-2000 period given the reliance herein on NCEP Reanalysis data to derive the circulation anomalies. Composite analysis was found to be appropriate for the ENSO dry summers, while the greater mid-latitude influence during non-ENSO dry summers necessitated dealing with these cases on an individual basis.

The tropical-extratropical cloud-bands that extend from an easterly disturbance over low-latitude southern Africa to a westerly disturbance southeast of South
Africa are responsible for a large proportion of the summer rainfall over the region (e.g. Harrison 1984, PrestonWhyte \& Tyson 1988). During the dry summers, these systems tend to be shifted offshore over the southwest Indian Ocean or be suppressed. This may happen if the ascending branch of the local Walker Circulation shifts offshore and/or if positive pressure anomalies and associated subsidence exist over southern Africa. Another important factor that is commonly associated with dry summers over northeastern South Africa is advection of relatively cool, dry South Atlantic air over South Africa rather than inflow of moist warm air from the north or the east.

During the strong ENSO dry summers, the large area of positive pressure anomalies that extends out across the Indian Ocean-southern Africa-Southeast Atlantic region from its centre over tropical Australasia leads to local subsidence and suppression of convection over southern Africa and weakening of the tropical low over southern Angola that is the source region for cloudbands. This ridging also leads to an equatorward expansion of the westerlies over the southeast Atlantic and South Africa, again unfavourable for cloud-band occurrence over South Africa. The upper-level westerly anomalies represent a weakening of the flow over lowlatitude southern Africa, reducing the tendency for barotropic instability and convection. South and southwest of South Africa, the upper-level westerly anomalies may act to steer frontal systems more towards southwestern South Africa and less to the southeast of

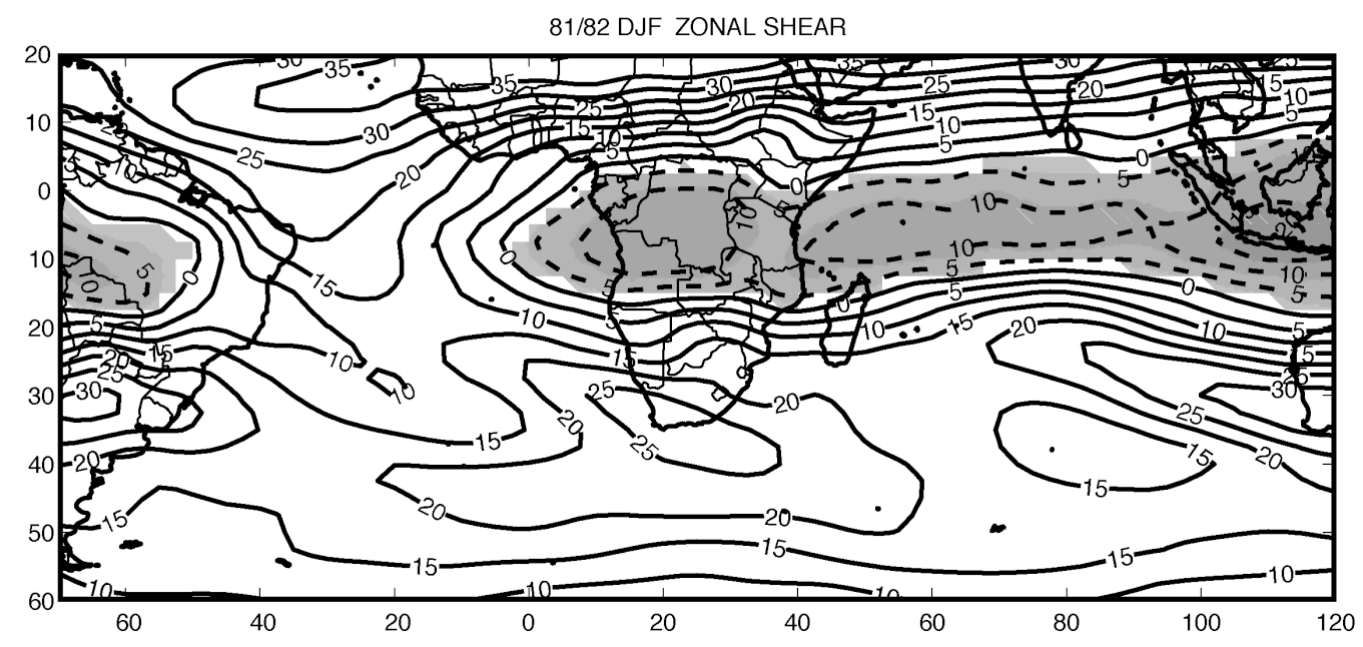

Fig. 19. Zonal wind shear between 850 and $200 \mathrm{hPa}$ (interval $=5 \mathrm{~m} \mathrm{~s}^{-1}$ ) for the DJF 1981/82 dry summer 
the country, which further discourages cloud-bands to extend northwest-southeast across South Africa. The neighbouring tropical oceans show warm anomalies (Reason et al. 2000), which tends to attract convection away from southern Africa and reduce its rainfall.

While the ENSO dry summers result from significant changes in the tropical circulation and SST, the analysis suggests that mid-latitude influences play a much bigger role in the non-ENSO dry seasons. Like the ENSO dry seasons, there is relative advection of cool, dry South Atlantic air over South Africa, which is unfavourable for cloud-bands; however, this tends to come about more from relatively large pressure anomalies situated in the mid-latitudes rather than from changes centred in the tropics as occurs during ENSO years. SST changes over the neighbouring tropical and subtropical oceans are much smaller than during ENSO years, and there is little evidence of any influence on rainfall. Over tropical southern Africa, the low- to mid-level circulation is generally, but not always, anticyclonic, further suggesting that it is the mid-latitude influence that is more important for dry summers during these non-ENSO years.

The significant mid-latitude influence during the non-ENSO dry summers may pose greater difficulties in forecasting them rather than the ENSO dry years, due to the weaker coupling between the ocean and atmosphere in the extratropics, less coherent signals in SST and potentially a greater role of internal atmospheric instabilities during non-ENSO cases. However, it should also be remembered that the ENSO signal over southeastern Africa tends to be less strong and coherent than that nearer the core tropical Indo-Pacific region (e.g. northern Australasia; Allan et al. 1996), and indeed, as already mentioned, there are strong ENSO years when conditions over northeastern South Africa were not particularly dry (1965/66) and in one case (1957/58) wetter than average. Unfortunately, this implies that South African seasonal forecasting is challenging during both ENSO and non-ENSO seasons and that a multitude of factors needs to be considered. These include regional and remote SST patterns, Antarctic sea-ice extent and thickness, pre-season soil and vegetation conditions over southern Africa and near-global circulation anomalies associated with phenomena such ENSO, the Southern Hemisphere annular mode and the interdecadal Pacific Oscillation. Future work is aimed at assessing these influences as well as considering the nature of wet seasons over the region.

Acknowledgements. The authors wish to thank the South African Water Research Commission, for partially funding this study, and the South African Weather Service, for making the rainfall data available. NCEP data were obtained from the Climate Prediction Center of NOAA.

\section{LITERATURE CITED}

Allan RJ, Lindesay JA, Parker D (1996) El-Nino Southern Oscillation and climatic variability. CSIRO, Mordialloc, Vic

Barclay JJ, Jury MR, Landman W(1993) Climatological and structural differences between wet and dry troughs over southern Africa in early summer. Meteorol Atmos Phys 51: 41-54

Camberlin P, Janicot S, Poccard I (2001) Seasonality and atmospheric dynamics of the teleconnection between African rainfall and tropical sea surface temperature: Atlantic vs. ENSO. Int J Climatol 21:973-1005

Cook KC (2000) The South Indian Convergence Zone and interannual rainfall variability over Southern Africa. J Clim 13:3789-3804

Cook KC (2001) A southern hemisphere wave response to ENSO with implications for Southern Africa precipitation. J Atmos Sci 58:2146-2162

D'Abreton PC, Lindesay JA (1993) Water vapour transport over southern Africa during wet and dry late summer months. Int J Climatol 13:151-170

Goddard L, Graham NE (1999) The importance of the Indian Ocean for GCM based climate forecasts over eastern and southern Africa. J Geophys Res 104:19099-19116

Godfred-Spenning C, Reason CJC (2002) Variability of lower tropospheric moisture transport during the Australian monsoon. Int J Climatol 22:509-532

Grist JP, Nicholson SE (2001) A study of the dynamic factors influencing the rainfall variability in West African Sahel. J Clim 14: 1337-1359

Harrison MSJ (1984) A generalised classification of South African summer rain bearing synoptic systems. J Climatol $4: 547-560$

Janowiak JE (1988) An investigation of interannual rainfall variability in Africa. J Clim 1:240-255

Jury MR (1992) A climatic dipole governing the interannual variability of convection over SW Indian Ocean and SE Africa region. Trends Geophys Res 1:165-172

Jury MR, McQueen CA, Levey KM (1994) SOI and QBO signals in the African region. Theor Appl Climatol 50: 103-115

Jury MR, Mulenga H, Rautenback H (2000) Tropical Atlantic variability and Indo Pacific ENSO. Statistical analysis and numerical simulation. Global Atmos Ocean Syst 7: 107-124

Kalnay E and 22 others (1996) The NCEP/NCAR Reanalysis 40 year Project. Bull Am Meteorol Soc 77:437-471

Karoly DJ, Vincent DG (1998) Meteorology of the Southern Hemisphere. Meteorol Monogr 27 (49)

Kiladis GN, Diaz HF (1989) Global climatic anomalies associated with extremes in Southern Oscillation. J Clim 2: 1069-1090

Kiladis GN, Mo KC (1998) Interannual and intraseasonal variability in the Southern Hemisphere. Meteorology of the Southern Hemisphere. Meteorol Monogr 25, American Meteorological Society, Boston, MA, p 307-336

Landman WA, Mason SJ (1999) Change in the association between Indian Ocean sea surface temperature and summer rainfall over South Africa and Namibia. Int J Climatol 19:1477-1492

Lindesay JA (1988) South African rainfall, the Southern Oscillation and a Southern Hemisphere semi-annual cycle. J Climatol 8:17-30

Mason SJ, Lindesay JA (1993) A note on the modulation of Southern Oscillation-southern African rainfall associations with Quasi-Biennial Oscillation. J Geophys Res 97: $5847-5856$ 
Miron O, Tyson PD (1984) Wet and dry conditions and pressure anomaly fields over South Africa and adjacent oceans 1963-1979. Mon Weather Rev 112:2127-2132

Mo KC (2000) Relationships between low-frequency variability in the southern hemisphere and sea surface temperature anomalies. J Clim 13:3599-3610

Nicholson SE, Kim J (1997) The relationship of the El-Nino Southern Oscillation to African rainfall. Int J Climatol 17: 117-135

Preston-Whyte RA, Tyson PD (1988) The atmosphere and weather of Southern Africa. Oxford University Press, Cape Town

Rasmusson EM, Carpenter TH (1982) Variations in tropical sea surface temperature and surface wind fields associated with the Southern Oscillation/El-Nino. Mon Weather Rev 110:354-384

Reason CJC (1999) Interannual warm and cool events in the subtropical/mid-latitude South Indian Ocean region. Geophys Res Lett 26:215-218

Reason CJC (2001) Subtropical Indian Ocean SST dipole events and southern African rainfall. Geophys Res Lett 28: 327-330

Reason CJC, Mulenga H (1999) Relationships between South African rainfall and SST anomalies in the south west Indian ocean. Int J Climatol 19:1651-1673

Reason CJC, Allan RJ, Lindesay JA, Ansell TJ (2000) ENSO and climatic signals across the Indian Ocean basin in the global context. Part 1, Interannual Composite patterns. Int J Climatol 20:1285-1327

Richard Y, Trzaska S, Roucou P, Rouault M (2000) Modification of the Southern African rainfall variability/ENSO relationship since late 1960's. Clim Dyn 16:883-895

Editorial responsibility: Andrew Comrie,

Tucson, Arizona, USA
Rocha A, Simmonds I (1997) Interannual variability of southeastern African summer rainfall. Part I. Relationships with air-sea interaction processes. Int J Climatol 17:235-265

Ropelewski CF, Halpert MS (1987) Global and regional-scale precipitation patterns associated with the El-Nino/Southern Oscillation. Mon Weather Rev 115:1606-1626

Ropelewski CF, Halpert MS (1989) Precipitation patterns associated with the high index phase of the southern Oscillation. J Clim 2:268-284

Ropelewski CF, Halpert MS (1996) Quantifying Southern Oscillation-precipitation relationships. J Clim 9: 1043-1059

South African Weather Bureau (1972) District rainfall for South Africa and the annual march of rainfall over southern Africa. South African Weather Bureau, WB35, Pretoria

Trenberth KE, Guillemot CJ (1998) Evaluation of the atmospheric moisture and hydrological cycle in the NCEP/ NCAR reanalyses. Clim Dyn 14:213-231

Tyson PD (1981) Atmospheric circulation variations and the occurrence of extended wet and dry spells over Southern Africa. J Climatol 1:115-130

Tyson PD (1984) The atmospheric modulation of extended wet and dry spells over South Africa 1958-1978. J Climatol 4:621-635

Tyson PD (1986) Climatic change and variability in Southern Africa. Oxford University Press, Cape Town

van Heerden J, Terblanche DE, Schulze G (1988) The Southern Oscillation and South African summer rainfall. Int J Climatol 8:577-597

Walker ND (1990) Links between South African summer rainfall and temperature variability of the Agulhas and Benguela Current systems. J Geophys Res 95:3297-3319

Submitted: October 25, 2002; Accepted: May 30, 2003

Proofs received from author(s): September 22, 2003 